\title{
Vancomycin-resistant Enterococcus faecium Empyema in an Asplenic Patient
}

\author{
Matthew J. Cotton ${ }^{1}$, Clifford D. Packer ${ }^{1}$ \\ 1. Internal Medicine, Case Western Reserve University School of Medicine, Cleveland, USA
}

Corresponding author: Matthew J. Cotton, mjc237@case.edu

\begin{abstract}
Enterococcal empyema is a rare complication of pneumonia. We report the case of a 67 -year-old asplenic man with pneumonia complicated by respiratory failure and empyema requiring decortication and prolonged chest tube drainage. Cultures of the empyema were initially negative, but later grew vancomycin-resistant Enterococcus faecium (VRE), which was successfully treated with linezolid. To our knowledge, this is only the second reported case of an empyema caused by VRE that was not associated with an intra-abdominal infection. We suspect superinfection due to airway or chest tube contamination as the most likely mechanism of infection. Physicians should consider multi-drug resistant organisms such as VRE in patients with empyema that fail to resolve with chest tube drainage and broad-spectrum antibiotics.
\end{abstract}

Received 03/12/2018

Review began 04/16/2018 Review ended 08/24/2018 Published 08/29/2018

๑) Copyright 2018

Cotton et al. This is an open access article distributed under the terms of the Creative Commons Attribution License CC-BY 3.0., which permits unrestricted use, distribution, and reproduction in any medium, provided the original author and source are credited.
Categories: Internal Medicine, Infectious Disease, Pulmonology

Keywords: empyema, enterocococcus faecium, asplenia, enterococci, vre, vacomyocin resistant enterococcus faecium, antimicrobrial resistance, clinical microbiology, infectious diseases, antimicrobials

\section{Introduction}

Enterococcus species are most commonly associated with gastrointestinal and urinary tract infections, bacteremia and endocarditis. Enterococcal pneumonia, empyema, and lung abscess are uncommon and often thought to result from colonization of the airways. We describe an asplenic patient with multiple comorbidities presenting with a prolonged course of pneumonia complicated by vancomycin-resistant Enterococcus faecium (VRE) empyema. The patient failed to respond to broad-spectrum antibiotics for two months until VRE grew from a pleural culture, after which he showed clinical improvement with linezolid therapy. While alcohol abuse and smoking are associated with Enterococcus empyema, asplenia has not previously been reported with it and may be an additional risk factor for the disease. VRE empyema is rare; to our knowledge, this is only the second reported case.

\section{Case Presentation}

A 67-year-old man with a history of chronic obstructive pulmonary disease, cerebral vascular accident, necrotizing pancreatitis complicated by pseudocyst requiring splenectomy and heart failure with preserved ejection fraction was transferred to our hospital following one month of treatment for pneumonia. He was a distant alcoholic but had since gone through rehabilitation and admitted to drinking one time per week and smoking four cigarettes a day. He had previously presented to his primary care physician with fever and malaise and was diagnosed with community-acquired pneumonia. He was treated with five days of azithromycin. He continued to worsen, and was admitted to an outside hospital with hypoxemia and right lower lobe pneumonia for which he was started empirically on vancomycin and piperacillin-tazobactam. His hospital course was complicated by respiratory failure requiring intubation for three days and a recurrent exudative right lung loculated effusion that required decortication and placement of a catheter that remained in place for two weeks. All blood and pleural fluid cultures were negative.

On transfer to our hospital for physical rehabilitation, the patient complained of mild shortness of breath. He denied hemoptysis, chest pain, orthopnea, nausea, chills or night sweats. Physical exam was significant for bilateral rhonchi with signs of consolidation in the right lower lobe. His labs were notable for a white blood cell count (WBC) of 17,000 cells/mcl with $87 \%$ neutrophils, and a chest radiograph revealed a right middle lobe infiltrate. He was continued on intravenous (IV) vancomycin and piperacillin-tazobactam at admission. Over the next two days his WBC climbed to 21,000 cells/mcl. Computed tomography scan of the chest revealed a right-sided empyema with extensive bilateral airspace disease consistent with severe pneumonia. A new chest tube was placed, which drained dark brown exudative fluid with gram-positive cocci on gram stain. The fluid was cultured and grew $E$. faecium resistant to ampicillin and vancomycin but sensitive to linezolid, gentamicin and streptomycin. The patient was started on linezolid and improved over the next two weeks, with resolution of the chest tube drainage.

\section{Discussion}

Enterococcus species are gram-positive facultative anaerobic cocci that are natural colonizers of the human gut. They frequently cause gastrointestinal, urinary tract and catheter associated infections as well as skin 
and soft tissue infections [1]. Of the enterococcus species, E. faecium is more difficult to treat due to higher levels of antibiotic resistance than is seen in Enterococcus faecalis.

Pneumonia and empyema due to enterococcus is a rare occurrence. A study of serious infections due to enterococcus infection found that over the course of one year there were 110 enterococcal infections across six hospitals with $4 \%$ of those infections located in the respiratory tract [2]. A trial done in the UK studying empyema treatment found that the most common causes of empyema were streptococci, enterobacteriaceae, anaerobic bacteria and staphylococcus [3]. This same study found cultured enterococci in three of 430 pleural fluid samples. Another study in 1993 found four cases of enterococcus empyema among 197 cases of empyema [4]. One recent case report and review of the literature found 11 cases of enterococcus pneumonia with monoculture of an enterococcus species not as a complication of intra-abdominal or gastrointestinal process or secondary to bacterial endocarditis (Table 1) [5]. Of these, one is reported as a case of VRE empyema in a

41-year-old man with HIV/AIDS and a CD4 count of 54 cells $/ \mathrm{mm}^{3}$ [5]. To our knowledge, this is the only other case of a non-abdominal related enterococcus with vancomycin resistance.

\begin{tabular}{|c|c|c|c|c|c|c|c|}
\hline Author (Year) & Age & Co-morbid condition & $\begin{array}{l}\text { Pleuro-pulmonary } \\
\text { infection }\end{array}$ & $\begin{array}{l}\text { Enterococcus } \\
\text { species }\end{array}$ & $\begin{array}{l}\text { Antibiotic } \\
\text { treatment }\end{array}$ & Other treatment & Outcome \\
\hline $\begin{array}{l}\text { Morris and Okies } \\
\text { (1974) }\end{array}$ & 54 & NA & $\begin{array}{l}\text { Pneumonia, lung } \\
\text { abscess }\end{array}$ & $\begin{array}{l}\text { Enterococcus } \\
\text { spp. }\end{array}$ & $\begin{array}{l}\text { Penicillin + } \\
\text { streptomycin }\end{array}$ & Chest tube & $\begin{array}{l}\text { Clinical } \\
\text { cure }\end{array}$ \\
\hline $\begin{array}{l}\text { Morris and Okies } \\
\text { (1974) }\end{array}$ & 46 & $\begin{array}{l}\text { PAD, CVA, smoker, } \\
\text { alcohol abuse }\end{array}$ & $\begin{array}{l}\text { Pneumonia, lung } \\
\text { abscess }\end{array}$ & $\begin{array}{l}\text { Enterococcus } \\
\text { spp. }\end{array}$ & $\begin{array}{l}\text { Ampicillin + } \\
\text { gentamicin }\end{array}$ & Chest tube & $\begin{array}{l}\text { Clinical } \\
\text { cure }\end{array}$ \\
\hline $\begin{array}{l}\text { Portero et al. } \\
\text { (1994) }\end{array}$ & 68 & Alcohol abuse, smoker & Pneumonıa, empyema & E. taeclum & Ciprofloxacın & Thoracentesıs & $\begin{array}{l}\text { Clinical } \\
\text { cure }\end{array}$ \\
\hline $\begin{array}{l}\text { Patterson et al. } \\
(1995)^{\star}\end{array}$ & NA & NA & Pneumonıa, empyema & NA & NA & NA & NA \\
\hline $\begin{array}{l}\text { Escudero et al. } \\
\text { (1995) }\end{array}$ & 78 & A. fib, CVA, CAD, HIN & Pneumonia, empyema & $\begin{array}{l}\text { Enterococcus } \\
\text { spp. }\end{array}$ & $\begin{array}{l}\text { Amoxicillin/ } \\
\text { clavulanate }\end{array}$ & Thoracentesıs & $\begin{array}{l}\text { Clinical } \\
\text { cure }\end{array}$ \\
\hline $\begin{array}{l}\text { Molinos et al. } \\
\text { (1995) }\end{array}$ & 49 & $\begin{array}{l}\text { Smoker, alcohol abuse, } \\
\text { alcoholic hepatitis }\end{array}$ & Pneumonıa & E. taecalis & Vancomycin & None & $\begin{array}{l}\text { Clinical } \\
\text { cure }\end{array}$ \\
\hline $\begin{array}{l}\text { Bergman et al. } \\
(2009)\end{array}$ & 63 & CVA & Pneumonıa, empyema & E. taecal/s & $\begin{array}{l}\text { Amoxicillin/ } \\
\text { clavulanate }\end{array}$ & $\begin{array}{l}\text { Thoracentesis, } \\
\text { chest tube }\end{array}$ & $\begin{array}{l}\text { Clinical } \\
\text { cure }\end{array}$ \\
\hline $\begin{array}{l}\text { Vanschooneveld } \\
\text { et al. (2009) }\end{array}$ & 41 & HIV & $\begin{array}{l}\text { Pneumonia, empyema, } \\
\text { lung abscess }\end{array}$ & E. faeclum & Linezolid & $\begin{array}{l}\text { Thoracentesis, } \\
\text { VATS }\end{array}$ & $\begin{array}{l}\text { Clinical } \\
\text { cure }\end{array}$ \\
\hline Our case & 67 & $\begin{array}{l}\text { Asplenia, COPD, CVA, } \\
\text { alcohol abuse }\end{array}$ & Pneumonıa, empyema & E. faeclum & Linezolid & $\begin{array}{l}\text { Chest tube, } \\
\text { VATS }\end{array}$ & $\begin{array}{l}\text { Clinical } \\
\text { cure }\end{array}$ \\
\hline \multicolumn{8}{|c|}{ TABLE 1: Cases of enterococcal pleuro-pulmonary infections. } \\
\hline \multicolumn{8}{|c|}{$\begin{array}{l}\text { VATS: Video-assisted thoracoscopic surgery; HIV: Human immunodeficiency virus; NA: Not available; CAD: Coronary artery disease; A. fib: Atrial } \\
\text { fibrillation; CVA: Cerebrovascular accident; HTN: Hypertension; PAD: Peripheral arterial disease; COPD: Chronic obstructive pulmonary disease. }\end{array}$} \\
\hline
\end{tabular}

Nosocomial enterococcal pneumonia is associated with older age and significant comorbidities and with abuse of tobacco and alcohol when acquired in the community [4]. Our patient was 67 years of age and had a distant history of alcohol abuse. It is unclear whether he developed an enterococcal pneumonia in the community, or if the VRE empyema was the result of a complicated community-acquired pneumonia of another type with subsequent VRE superinfection. Blood and pleural cultures taken at the outside hospital were negative, which raises the likelihood that superinfection occurred at some point during his hospitalization. One important point in this case to consider is antibiotic stewardship. Use of vancomycin can predispose a patient to subsequently developing VRE [6]. Our patient received a long course of vancomycin that may have increased his odds for acquisition of a drug resistant strain of bacteria.

Interestingly, our patient had asplenia, which is not considered a risk factor for enterococcus pneumonia. Asplenia leaves patients highly susceptible to bacteremia with gram-positive cocci and subsequent serious infection, especially with encapsulated organisms [7]. Some strains of VRE have been reported to produce capsular polysaccharides [8], which could increase risk for bacteremia in asplenic patients. It is possible that 
E. faecium bacteremia might have complicated this patient's pleuro-pulmonary infection, with hematogenous seeding and superinfection of the partially treated empyema. However, there is no clear source of secondary infection that might have caused a VRE bacteremia. Direct exposure to E. faecium in the hospital environment, such as contamination of his chest tube or endotracheal tube, is another possibility. Snyder et al. found that gowns and gloves worn as infection-control protective barriers are frequently contaminated with methicillin-resistant Staphylococcus aureus and VRE, particularly during the care of the patient's respiratory tract [9]. Another case report by Cian et al. found that the tip of a thoracic catheter was colonized by $E$. faecalis resistant to vancomycin and linezolid in the absence of previous exposure to these antibiotics [10].

Other causes of enterococcal empyema are noteworthy but were not the focus of this discussion given the nature of the case. Spontaneous bacterial empyema is seen in cirrhotic patients and is thought to occur secondary to intra-abdominal infections seeding through a hydrothorax. One prospective study found enterococcus isolates in $2 / 24$ cases of spontaneous bacterial empyema in cirrhotic patients with hydrothorax [11]. There also have been reports of enterococcal empyema seen in conjugation with endocarditis [12] and an interesting case in a patient with nephrotic syndrome who developed bilateral empyema, albeit they were not enterococcal [13]. We suggest a thorough examination of the patient with enterococcal empyema to identify a secondary source of infection given the diverse sources of infection.

\section{Conclusions}

Physicians should consider VRE as a possible etiology of an empyema that is unresponsive to broadspectrum antibiotics, especially in smokers, alcohol abusers, and patients with asplenia or immunosuppression. VRE bacteremia or direct contamination of chest or endotracheal tubes are possible causes of VRE superinfection in cases of pneumonia complicated by empyema.

\section{Additional Information \\ Disclosures}

Human subjects: Consent was obtained by all participants in this study. Conflicts of interest: In compliance with the ICMJE uniform disclosure form, all authors declare the following: Payment/services info: All authors have declared that no financial support was received from any organization for the submitted work. Financial relationships: All authors have declared that they have no financial relationships at present or within the previous three years with any organizations that might have an interest in the submitted work. Other relationships: All authors have declared that there are no other relationships or activities that could appear to have influenced the submitted work.

\section{References}

1. Arias CA, Murray BE: The rise of the enterococcus: beyond vancomycin resistance . Nat Rev Microbiol. 2012, 10:266-278. 10.1038/nrmicro2761

2. Patterson JE, Sweeney AH, Simms M, Carley N, Mangi R, Sabetta J, Lyons RW: An analysis of 110 serious enterococcal infections epidemiology, antibiotic susceptibility, and outcome. Medicine (Baltimore). 1995, 74:191-200.

3. Maskell NA, Davies CW, Nunn AJ, et al.: U.K. controlled trial of intrapleural streptokinase for pleural infection. N Engl J Med. 2005, 352:865-874. 10.1056/NEJMoa042473

4. Brook I, Frazier EH: Aerobic and anaerobic microbiology of empyema. A retrospective review in two military hospitals. Chest. 1993, 103:1502-1507. 10.1378/chest.103.5.1502

5. Vanschooneveld T, Mindru C, Madariaga MG, Kalil AC, Florescu DF: Enterococcus pneumonia complicated with empyema and lung abscess in an HIV-positive patient. Case report and review of the literature. Int J STD AIDS. 2009, 20:659-661. 10.1258/ijsa.2008.008456

6. Carmeli Y, Samore MH, Huskins WC: The association between antecedent vancomycin treatment and hospital-acquired vancomycin-resistant enterococci: a meta-analysis. Arch Intern Med. 1999, 159:24612468. 10.1001/archinte.159.20.2461

7. Rubin LG, Schaffner W: Care of the asplenic patient. N Engl J Med. 2014, 371:349-356. 10.1056/NEJMcp1314291

8. Huebner J, Wang Y, Krueger WA, et al.: Isolation and chemical characterization of a capsular polysaccharide antigen shared by clinical isolates of enterococcus faecalis and vancomycin-resistant enterococcus faecium. Infect Immun. 1999, 67:1213-1219.

9. Snyder GM, Thom KA, Furuno JP, et al.: Detection of methicillin-resistant staphylococcus aureus and vancomycin-resistant enterococci on the gowns and gloves of healthcare workers. Infect Control Hosp Epidemiol. 2008, 29:583-589. 10.1086/588701

10. Cian F, Luzzati R, Deiana ML, Ferrantelli N, Tonin E, Lagatolla C, Dolzani L: Colonization of the tip of a thoracic catheter by Enterococcus faecalis resistant to vancomycin and linezolid. J Med Microbiol. 2009, 58:1118-1121. 10.1099/jmm.0.008334-0

11. MacEachern P, Giannoccaro JP, Elsayed S, Read RR, Laupland KB: A rare case of pleuropulmonary infection and septic shock associated with Enterococcus faecium endocarditis. J Infect. 2005, 50:84-88. 10.1016/j.jinf.2003.11.005

12. Tornos MP, Mayor G, Nadal A, Soler-Soler J: Empyema and splenic abscess in infective endocarditis . Int J Cardiol. 1984, 6:746-748. 10.1016/0167-5273(84)90304-8

13. Chen WC, Huang JW, Chen KY, Hsueh PR, Yang PC: Spontaneous bilateral bacterial empyema in a patient 


\section{Cureus}

with nephrotic syndrome. J Infect. 2006, 53:131-134. 10.1016/j.jinf.2005.12.003 